\title{
Łukasz Cymbaluk
}

ORCID: 0000-0003-1868-3869

Uniwersytet Wrocławski

\section{Bitcoin i polityczne implikacje kryptowalut}

https://doi.org/10.19195/1643-0328.29.5

Słowa kluczowe: bitcoin, blockchain, kryptowaluty, państwo, sankcje gospodarcze

\section{Wstęp}

Pojawienie się bitcoina i innych kryptowalut doprowadziło do wielu zmian w przestrzeni ekonomicznej oraz politycznej. W efekcie zauważalny stał się wpływ i wynikające z niego konsekwencje funkcjonowania tego rodzaju instrumentów wobec poszczególnych państw. Wskazać można przypadki wyraźnych reakcji na zaistniałe zjawisko kryptowalut. Dostrzegalne są w tym kontekście zarówno obawy dotyczące bezpieczeństwa, jak i zainteresowanie możliwościami wykorzystywania walut cyfrowych na rzecz realizacji założeń politycznych.

Celem artykułu jest przedstawienie głównych cech kryptowaluty bitcoin oraz analiza sposobów, w jaki wpływa ona na sferę polityczną, związaną przede wszystkim z procesami funkcjonowania państw oraz kluczowymi obszarami ich aktywności. Próbie weryfikacji zostanie poddana hipoteza zakładająca, że powstanie bitcoina doprowadziło do dających się zidentyfikować reakcji ze strony aktorów państwowych. Autor spróbuje udzielić odpowiedzi na pytanie, w jakich obszarach aktywności państw są widoczne skutki powstania i funkcjonowania bitcoina, a także jakie mechanizmy, cechy lub funkcje tej kryptowaluty generują szczególne zainteresowanie. Kolejne pytanie dotyczy zakresu zastosowań i możliwości wykorzystywania tego rodzaju instrumentów przez państwa. W artykule podjęto też próbę wyjaśnienia kwestii, czy istnienie kryptowalut może być zasadnie postrzegane jako problem i zagrożenie z punktu widzenia aktorów politycznych oraz ich najbardziej żywotnych interesów.

Bitcoin oraz pozostałe kryptowaluty to zjawisko nowe i dynamicznie się rozwijające. W rezultacie zagadnienie to ma jeszcze małe podstawy teoretyczne. Prowadzone w tym zakresie badania można określić jako znajdujące się w początkowej fazie rozwoju. Dotychczasowe pozycje poświęcone zagadnieniu koncentrują się głównie na aspektach 
technologicznych, ekonomicznych i finansowych. Znaczną częścią wspomnianej literatury są poradniki dotyczące aktywności inwestycyjnej. Można także zaobserwować zainteresowanie problematyką wśród przedstawicieli nauk prawnych, co skutkuje publikacjami omawiającymi zjawisko w kontekście legislacyjnym i regulacyjnym. Wyraźny jest natomiast deficyt w zakresie analiz politologicznych. Uzupełnienie literatury tworzyć mogą liczne doniesienia medialne oraz teksty $\mathrm{z}$ witryn internetowych poświęconych kryptowalutom. Treść artykułu oraz zawarte w nim analizy odnoszą się do stanu wiedzy z 2019 roku.

\section{Bitcoin - definicja i charakterystyka}

Bitcoin (w skróconej formie BTC) nie ma wyraźnie prostej i powszechnie przyjętej definicji. Najczęściej wskazuje się, iż jest to rodzaj waluty lub też forma pieniądza. Podkreślane jest też niekiedy wykorzystywanie w jego funkcjonowaniu komputerów oraz sieci internetowej, co sprawia, że bitcoin określany jest jako waluta cyfrowa ${ }^{1}$. W ten sposób wyraźnie zaznaczane są różnice w stosunku do dotychczasowych środków płatności.

Bitcoin najczęściej jest przedstawiany jako kryptowaluta. Określenie to może być rozumiane na dwóch płaszczyznach. W pierwszym ujęciu, przedrostek 'krypto' sugeruje podobieństwo instrumentu do tradycyjnych walut. Drugie rozumienie opiera się w znacznym stopniu na kwestiach technicznych. Podkreślana jest w ten sposób niematerialna forma waluty, której działanie opiera się na stosowaniu kryptografii ${ }^{2}$. Dlatego zdaniem niektórych badaczy można zastosować inne nazewnictwo - waluta kryptograficzna ${ }^{3}$. Z kryptografią i sferą informatyczną wiąże się sieciowość, będąca istotną cechą bitcoina. W takim ujęciu tworzy on podstawę o zdecentralizowanym charakterze zawierającą informacje „o przepływach pewnych wartości liczbowych między kontami użytkowników systemu"

O decentralizacji można mówić $\mathrm{w}$ dwóch głównych wymiarach. W pierwszym wymiany kryptowaluty odbywają się na zasadzie peer-to-peer (P2P), czyli bezpośrednio pomiędzy użytkownikami. W drugim, bardziej istotnym, znaczeniu całokształt systemu jest niezależny od władz centralnych czy pośredników, a sama sieć oparta jest na konsensusie ${ }^{5}$. W tym kontekście decentralizacja oznacza, że żadna instytucja, w tym banki centralne, a nawet państwa nie sprawują nad bitcoinem w żaden sposób kontroli. Odnosi się to również do jego wartości, która jest wyznaczana wyłącznie przez rynek i działające na nim siły podaży i popytu ${ }^{6}$. Nie występuje też żadna instytucja odpowie-

${ }^{1}$ K. Kopańko, M. Kozłowski, Bitcoin. Złoto XXI wieku, Gliwice 2015, s. 15.

2 A.I. Piotrowska, Bitcoin. Płatnicze i inwestycyjne zastosowanie kryptowaluty, Warszawa 2018, s. 12.

${ }^{3}$ Ł. Stefanowicz, R. Wiśniewski, G. Brzydło, Możliwości zastosowania waluty kryptograficznej Bitcoin, [w:] Transakcje i monety internetowe. Kryptologia a biznes - bezpieczeństwo stosowane, red. M. Węgrzyn, J. Jabłoński, M. Nowakowski, Legionowo 2014, s. 79-86.

${ }^{4}$ M. Szymankiewicz, Bitcoin. Wirtualna waluta internetu, Gliwice 2014, s. 22.

${ }^{5}$ Ze strony oficjalnej bitcoina: www.bitcoin.org/pl/faq (dostęp: 29.04.2019).

${ }^{6}$ K. Kopańko, M. Kozłowski, op. cit., s. 15. 
dzialna za jego emisję. Bitcoin może być rozpatrywany z perspektywy ogólnofinansowej. $\mathrm{W}$ tym aspekcie jest traktowany jako pieniądz lub pieniądz cyfrowy. Wynika to z pełnienia tych samych funkcji. W literaturze wskazuje się, że „klasyczny” pieniądz służy jako środek wymiany, środek tezauryzacji oraz miernik wartości ${ }^{7}$. Najważniejszym podobieństwem do pieniądza jest to, że bitcoin umożliwia dokonywanie płatności za dobra i usługi. Kryptowaluta może też służyć jako instrument inwestycyjny. Istotna jest również wartość wynikająca z rzadkości występowania. Całkowita, a zarazem nieprzekraczalna liczba bitcoinów, jaka może znajdować się w obiegu, jest ściśle określona i wynosi w przybliżeniu 21 milionów ${ }^{8}$.

Zaznaczyć należy, że chociaż kryptowaluta spełnia najistotniejsze kryteria pieniądza, to postawienie znaku równości pomiędzy tymi pojęciami nie jest w pełni właściwe. Istnieją wyraźne różnice, takie jak to, że nie ma centralnego emitenta, kwestia powszechnej akceptowalności oraz że bitcoin jest środkiem wymiany tylko w ograniczonym zakre$\operatorname{sie}^{9}$. Nieistnienie instytucji odpowiedzialnej za nadzór i emisję nie umożliwia też na jednoznacznej kwalifikacji instrumentu za pieniądz elektroniczny ${ }^{10}$. „E-pieniądz” jest nadzorowany przez ten sam organ centralny co podstawowa krajowa jednostka płatnicza, a także w odróżnieniu od bitcoina nie jest to osobna waluta ${ }^{11}$.

Pomimo wirtualnego charakteru i roli internetu w działaniu kryptowaluty wykluczyć również należy stosowanie w tym kontekście określenia 'wirtualny pieniądz'. Choć taki rodzaj instrumentu można nabyć za rzeczywiste środki, to funkcjonuje on wyłącznie w ramach rzeczywistości wirtualnej, w której służy do zakupu dóbr wirtualnych ${ }^{12}$.

Podsumowując, zauważyć można, że bitcoin zawiera w sobie określone cechy charakterystyczne dla dotychczasowych środków płatniczych. Jest to w istotnej mierze system wymiany informacji służący przeprowadzaniu wymian. Całokształt działania oraz wartość instrumentu wynika ze zgody, zaufania i umowy zawieranej pomiędzy korzystającymi z niego stronami. W dalszym ciągu trwają spory o definicję oraz kwestię, czy bitcoin może być traktowany jako waluta, pieniądz czy pieniądz elektroniczny. Nawet jeżeli instrument jest postrzegany jako przykład środka płatniczego lub rodzaj pieniądza, przeważnie pojawiają się zastrzeżenia, iż nie jest to w pełni legalny środek płatniczy ${ }^{13}$. Wydaje się, że sformułowanie 'kryptowaluta' jest szczególnym kompromisem, jeżeli chodzi o stosunkowo prosty i przystępny sposób przedstawienia definicji oraz natury bitco-

7 Ekonomia od A do Z, red. S. Sztaba, Warszawa 2007, s. 339.

8 B. Guttman, The Bitcoin Bible Gold Edition. All You Need to Know about Bitcoins and More, Norderstedt 2013, s. 13.

9 A.I. Piotrowska, op. cit., s. 67-69.

10 Pieniądz elektroniczny (cyfrowy) - jest to wartość zapisana w formie cyfrowej. Pieniądz elektroniczny jest efektem procesów digitalizacji środków płatniczych.

11 S. Rotman, Bitcoin versus Electronic Money, CGAP Brief, 23 January 2014, s. 2, www.cgap.org/sites/ default/files/Brief-Bitcoin-versus-Electronic-Money-Jan-2014.pdf (dostęp: 30.04.2019).

12 T. Smus, M. Maciejasz-Świątkiewicz, Czym jest pieniądz wirualny?, [w:] Pieniądz wirtualny $i$ determinanty jego rozwoju w sferze ekonomii, finansów, prawa, red. E. Bogacka-Kisiel, Opole 2013, s. 20. Pieniądz wirtualny jest to forma pieniądza funkcjonująca w konkretnym środowisku rzeczywistości wirtualnej, na przykład w grach sieciowych. Szerzej ibidem, s. 16-21.

13 P. Lis Markiewicz, S. Nowak, Bitcoin. Przyszłość inwestowania, Warszawa 2015, s. 50. 
ina. Jest to jednocześnie potocznie przyjęty i powszechnie stosowany zwrot. Zaznaczyć należy, że funkcjonuje także określenie „waluta cyfrowa”. Choć w ten sposób akcentowane są nieco odmienne elementy specyfiki bitcoina, to takie nazewnictwo również może być uzasadnione.

\section{Początki i rozwój}

Początki bitcoina sięgają 2008 roku, w którym ukazał się artykuł opisujący koncepcję oraz specyfikację systemu funkcjonowania kryptowaluty. Tak zwany Manifest ${ }^{14}$ opatrzony został nazwiskiem Satoshi Nakamoto. Sama tożsamość pomysłodawcy i twórcy bitcoina do dziś jest niejasna i wzbudza kontrowersje. Przypuszcza się, że Satoshi Nakamoto to pseudonim. Istnieją również podejrzenia, że za projektem może stać nie pojedyncza osoba, lecz grupa programistów. W 2014 roku, w wyniku śledztwa dziennikarskiego, dokonano próby ustalenia tożsamości twórcy kryptowaluty. Miał nim być Amerykanin japońskiego pochodzenia Dorian Nakamoto ${ }^{15}$. Kontrowersje pojawiły się ponownie rok później, kiedy australijski programista Craig Wright publicznie ogłosił, że jest odpowiedzialny za stworzenie podstaw działania instrumentu. Przedstawione dowody nie zostały jednak uznane za wiarygodne ${ }^{16}$.

Niezależnie od kwestii tożsamości twórcy (lub twórców), sam system został wdrożony do działania w 2009 roku. Warto dodać, że przy opracowaniu całokształtu działania kryptowaluty wykorzystano niezaimplementowane wcześniej rozwiązania informatyczne ${ }^{17}$. Dwa lata później „twórca” pozostawił cały projekt, w tym kod źródłowy, społeczności programistów i zniknął z życia publicznego. Wydarzenie to podkreśliło na swój sposób, że bitcoin jest oprogramowaniem w pełni otwartym i ogólnodostępnym (open source) oraz że nawet sam twórca nie sprawuje kontroli nad całokształtem systemu. Swobodny dostęp umożliwia analizę i dalsze udoskonalanie kodu źródłowego przez programistów z całego świata. Z momentem upublicznienia rozpoczął się intensywny rozwój kryptowaluty. Znacząco zaczęła wzrastać liczba użytkowników oraz dokonywanych transakcji.

Istotnym etapem rozwoju bitcoina był rok 2013. Okres ten charakteryzował się zwiększeniem sektora „wydobycia” kryptowaluty. Wystąpiły także większe wzrosty i wahania w cenie. Pierwsze poważne spadki cenowe były rezultatem zamknięcia witryny Silk Road $^{18}$. Serwis na dużą skalę wykorzystywał płatności bitcoinami w celu zapewnienia

14 S. Nakamoto, Bitcoin: A Peer-to-Peer Electronic Cash System, www.bitcoin.org/bitcoin.pdf (dostęp: 2.05.2019).

15 www.newsweek.com/2014/03/14/face-behind-bitcoin-247957.html (dostęp: 2.05.2019).

16 www.bitcoin.pl/wiadomosci/bezpieczenstwo/1212-craig-wright-nie-jest-satoshim-nakamotooszust-zdemaskowany (dostęp: 2.05.2019).

17 P. Franco, Understanding Bitcoin. Cryptography, Engineering and Economics, Padstow 2015, s. 161168.

18 Silk Road - sklep internetowy działający w ukrytej sieci TOR. Za pośrednictwem strony można było nabyć nielegalny asortyment, przede wszystkim narkotyki, broń czy też kradzione karty kredytowe. Witrynę 
anonimowości stronom transakcji. Pomimo znaczącego spadku pod koniec roku cena kryptowaluty osiągnęła rekordową wówczas wartość około 1200 dolarów. Gwałtowne wzrosty zostały jednak w niedługim czasie zahamowane. Przyczyną kolejnego spadku był $\mathrm{w}$ istotnej mierze zakaz przeprowadzania transakcji powiązanych $\mathrm{z}$ bitcoinem wydany przez Bank Centralny w Chinach ${ }^{19}$.

W ciągu kolejnych lat zainteresowanie kryptowalutą stopniowo rosło, a kurs ceny cechowała raczej mała zmienność oraz stopniowe wzrosty. Bitcoin sukcesywnie stawał się też akceptowany jako środek płatniczy przez coraz większą liczbę podmiotów i punktów sprzedaży. Jako przykład wskazać można Wikipedię oraz liczne firmy międzynarodowe, w tym Microsoft.

Dopiero rok 2017 przyniósł ogólnoświatowe zainteresowanie kryptowalutą. W marcu cena jednego bitcoina przekroczyła wartość jednej uncji złota. Kurs wyznaczał kolejne rekordy, aż osiągnął poziom blisko 19800 dolarów. Bitcoin i jego cena stały się wyznacznikami największej w historii bańki spekulacyjnej ${ }^{20}$. Pod względem skali i zasięgu wzrostu kryptowaluta zdeklasowała klasyczną „tulipomanię” z XVII wieku. Podobnie jak w historycznym przykładzie spekulacji także i w tym przypadku nastąpił krach. Obecnie kurs oscyluje na poziomie zbliżonym od 7500 dolarów za jednego bitcoina, co pozwala mówić o blisko sześćdziesięcioprocentowym spadku ceny (stan na pierwszą połowę 2019 roku).

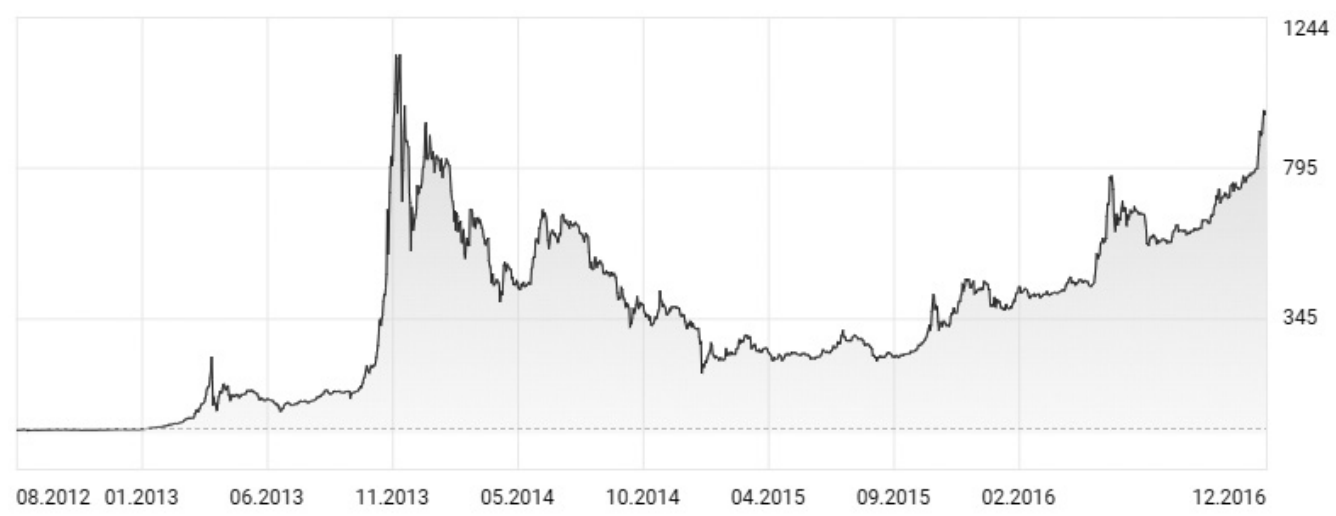

Wykres 1. Cena bitcoina w stosunku do dolara amerykańskiego do 2016 roku

$\mathrm{Na}$ wykresie widoczne jest pierwsze załamanie kursu z roku 2013, a następnie intensywny wzrost ceny i kolejny krach.

Źródło: www.money.pl/pieniadze/bitcoin/bitstamp,BTCSTAMPUSD,USD.html (dostęp: 5.05.2019).

zamknięto w 2013 roku w wyniku działań organów ścigania Stanów Zjednoczonych. Warto zaznaczyć, że podjęto próby przywrócenia strony do działania. Więcej zob. www.bitcoin.pl/97-publicystyka/422-przed-ipo-silk-road-1-0-ewolucja-internetowego-czarnego-rynku oraz www.dailydot.com/layer8/silk-road-3-blake-benthall (dostęp: 3.05.2019).

19 C. Evans, A. Novikov, V. Vitaliev, To bit or not to bit, „Engineering \& Technology” 9, 2014, nr 4, s. 84.

20 www.money.pl/impact17/,25,0,2393881.html (dostęp: 5.05.2019). 


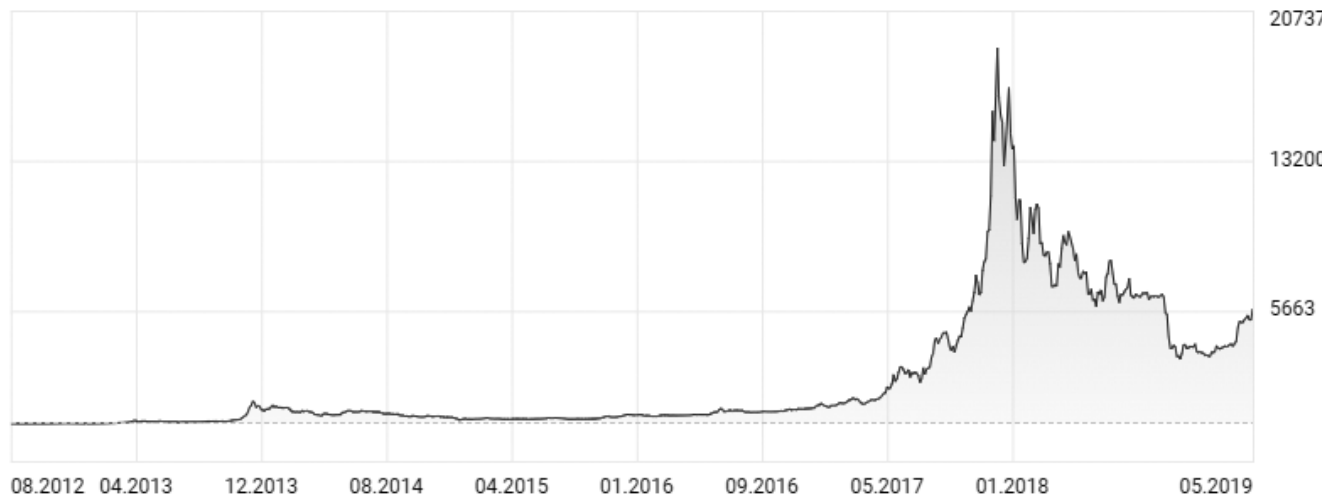

Wykres 2. Wykresy zmian ceny BTC/USD od początku istnienia kryptowaluty

Na wykresie widoczne są zmiany ceny w 2013 roku oraz ich skala w stosunku do „wielkiej bańki” spekulacyjnej z końca 2017 roku. Warto dodać, że wykres ten przypomina „bańkę tulipanową” - klasyczny przykład spekulacji.

Źródło: www.money.pl/pieniadze/bitcoin/bitstamp,BTCSTAMPUSD,USD.html (dostęp: 5.05.2019).

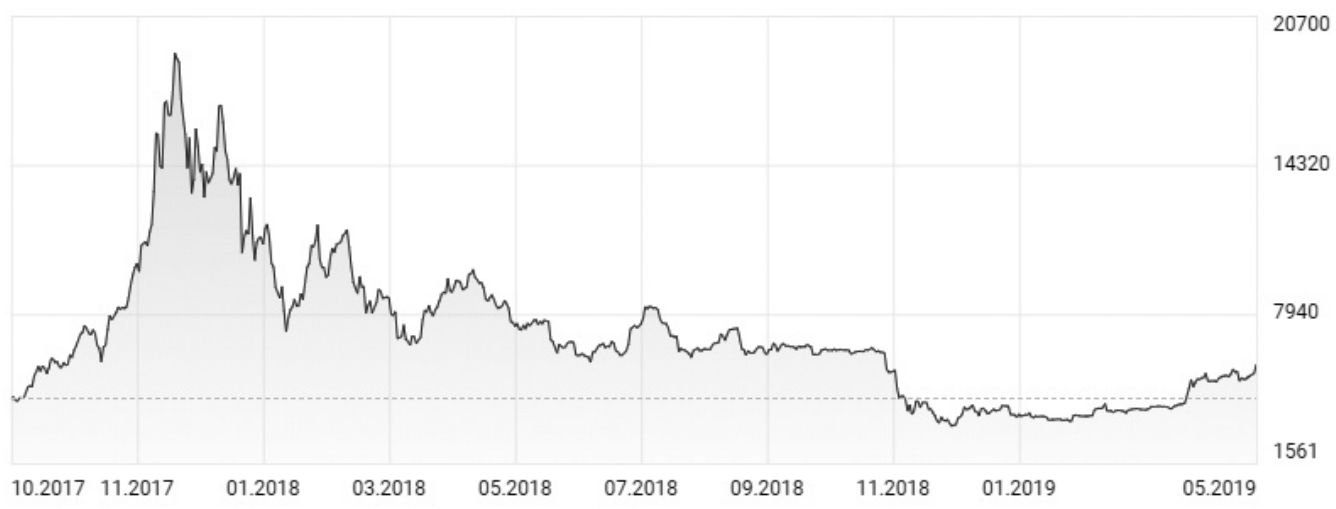

Wykres 3. Wykresy zmian ceny BTC/USD od okresu poprzedzającego ostatni krach do maja 2019 roku Widoczny jest proces spadków ceny oraz dalszy trend po załamaniu.

Źródło: www.money.pl/pieniadze/bitcoin/bitstamp,BTCSTAMPUSD,USD.html (dostęp: 5.05.2019).

Bitcoin zapoczątkował trend powstawania kolejnych kryptowalut. Mają one często zbliżone bądź identyczne zastosowanie, zasady i mechanizmy funkcjonowania co pierwowzór. Do najbardziej istotnych przykładów zaliczyć można Ethereum, Ripple, Dash, Litecoin czy Lisk. Istnieje również obszerna lista kryptowalut o mniejszym lub większym $z^{2 n a c z e n i u}{ }^{21}$. Powstawanie i rozwój kolejnych kryptowalut alternatywnych (tak zwanych altcoins) wynika $\mathrm{z}$ otwartego dostępu do skryptu bitcoina. Wśród ogromnej ilości altco-

${ }^{21}$ Całkowita liczba kryptowalut (na dzień 5.05.2019) wynosi 2525. Pełna lista dostępna pod adresem: https://pl.investing.com/crypto/currencies (dostęp: 5.05.2019). 
inów zdarzają się też projekty nastawione zasadniczo na generowanie sztucznego popytu i zgromadzenie kapitału przez twórców w czasie wprowadzenia instrumentu do obrotu, a $\mathrm{w}$ rezultacie oszukanie inwestoró $\mathrm{w}^{22}$. W konsekwencji tak zwane shitcoiny nie posiadają wartości technologicznej, cechują się znikomym znaczeniem, a ich cena w krótkim czasie po rozpoczęciu funkcjonowania na rynku jest zbliżona do zera ${ }^{23}$.

Pomimo istnienia licznych alternatyw bitcoin dalej pozostaje głównym przedstawicielem kryptowalut, utrzymując przy tym największy udział tego rynku. Ponadto sytuacja pozostałych walut cyfrowych (często również ich ceny) jest w istotnej mierze odzwierciedleniem tego, co się dzieje w danej chwili z samym bitcoinem. Dlatego można mówić o określonym stopniu zależności pomniejszych kryptowalut od koniunktury ich głównego przedstawiciela 24 .

Zaznaczyć należy, że mimo podobieństw, a niekiedy nawet bliźniaczych cech w stosunku do bitcoina, kryptowaluty są bardzo zróżnicowanym zbiorem. Mogą one mieć odmienne lub nawet wyjątkowe właściwości.

\section{Najważniejsze mechanizmy}

Funkcjonowanie systemu bitcoin jest nierozerwalnie związane z określonymi mechanizmami. Mają one znaczenie w odniesieniu do funkcji, możliwości zastosowania instrumentu. Są również elementem wyjaśniającym charakter kryptowaluty. Wyodrębnić można proces „wydobycia” („kopania”), realizowania transakcji oraz towarzyszący im łańcuch bloków. Wszystkie te mechanizmy są ściśle z sobą skorelowane, a ich suma składa się na całościowe działanie systemu.

\section{a) „Wydobycie"}

Każdy kolejny bitcoin powstaje w wyniku procesu zwanego „wykopywaniem” (mining). Kryptowaluta przyznawana jest w formie gratyfikacji użytkownikom udostępniającym moc obliczeniową swoich urządzeń na rzecz przetwarzania i szyfrowania ogółu przeprowadzanych transakcji. Obliczenia kryptograficzne dokonywane w trakcie procesu zapewniają prawidłowe działanie całej sieci bitcoin. Za swój wkład „górnicy” otrzymują od systemu kryptowalutę $\mathrm{w}$ formie nagrody ${ }^{25}$. Proces wydobywania charakteryzuje się

\footnotetext{
${ }^{22}$ ICO (Initial Coin Offering) - wprowadzenie kryptowaluty do obiegu. Celem jest przyciągnięcie inwestorów i kapitału na dalsze rozwijanie projektu. Proces jest w pewnym sensie analogiczny do wprowadzania spółek na giełdę (IPO - Initial Public Offering).

${ }^{23}$ S. Bentyn, M. Grzybkowski, Kryptowaluty. Dlaczego jeden bitcoin wart będzie milion dolarów?, Poznań 2018, s. 76.

${ }^{24}$ Silna korelacja kryptowalut widoczna była przykładowo podczas spadków ceny bitcoina z 6,4 do około 4,5 tysiąca dolarów. Więcej zob. www.bankier.pl/wiadomosc/Kurs-bitcoina-spada-z-sila-wodospaduGwaltownie-traca-takze-inne-kryptowaluty-7627478.html (dostęp: 8.05.2019).

25 D. Homa, Sekrety bitcoina i innych kryptowalut. Jak zmienić wirtualne pieniądze w realne zyski, Gliwice 2015, s. 116-117.
} 
wzrastającym poziomem trudności. Coraz większe staje się też ryzyko, które jest związane z malejącym prawdopodobieństwem osiągnięcia zysku oraz coraz większą konkurencją.

Wydobycie w swoim głównym założeniu ma zapewnić funkcjonowanie oraz bezpieczeństwo całemu systemowi ${ }^{26}$. Mechanizm stanowi podstawę rozrachunków zdecentralizowanych. Wszelkie transakcje rejestrowane są w blokach, do których utworzenia niezbędne są dokonywane przez użytkowników obliczenia. Tak zwane rozwiązanie poszczególnego bloku jest równoznaczne z jego weryfikacją i dodaniem go do publicznego łańcucha, który jest rozwijany od samego początku istnienia bitcoina ${ }^{27}$. Opisany mechanizm powstawania kryptowaluty jest jednocześnie podstawowym elementem związanym z procesami zatwierdzenia transakcji.

\section{b) Transakcje}

Bitcoin jest systemem w znaczącej mierze realizującym funkcje płatnicze. Podobnie jak tradycyjny pieniądz służy on do dokonywania płatności za towary i usługi. Proces ten polega głównie na przesyłaniu informacji ${ }^{28}$. Transakcje sprowadzają się do autoryzacji transferu środków do nowego właściciela. Wymianę rozpoczyna strona inicjująca, tworząc zlecenie zawierające informację o ustalonej liczbie bitcoinów oraz adres (klucz publiczny) ich nowego posiadacza. Proces zostaje poddany weryfikacji przez system, który sprawdza kwoty oraz poprawność kluczy prywatnych. Po zatwierdzeniu operacja jest zapisywana w zbiorze bloków zawierających spis wszystkich dotychczasowych transakcji. W przekazie środków może być zawarta kwota prowizji, która przeznaczona jest na rzecz „górników” pełniących funkcję kontrolną i rozliczeniową.

Każdy użytkownik systemu bitcoin ma dwa rodzaje kluczy — klucz prywatny i publiczny. Klucz publiczny, tak zwany portfel ${ }^{29}$, to odpowiednik numeru konta bankowego i jest zazwyczaj generowany przez oprogramowanie znajdujące się w komputerze lub innym urządzeniu użytkownika ${ }^{30}$. Klucz prywatny może być porównany do formy podpisu, którego wymaga zatwierdzanie transakcji. Jest to jednocześnie dowód, że zlecenie przekazania środków zostało zainicjowane przez ich rzeczywistego posiadacza. Całość procesu wymiany kryptowaluty zachodzi w sieci P2P, czyli bezpośrednio pomiędzy użytkownikami. Taki stan rzeczy zapewnia anonimowość transakcji.

W celu ułatwienia płatności bitcoin podzielony jest na mniejsze części. Najmniejszą jednostką kryptowaluty jest 'satoshi'. Nazewnictwo to nawiązuje do twórcy systemu. Jeden satoshi to 0,000 00001 część jednego bitcoina. Choć waluta cyfrowa nie ma fizycznej postaci i występuje tylko w sieci internetowej, to może być także przechowywana na

26 A.M. Antonopoulos, Bitcoin dla zaawansowanych. Programowanie z użyciem otwartego łańcucha bloków, przeł. T. Walczak, Gliwice 2018, s. 223.

27 D. Homa, op. cit., s. 39-40.

28 K. Kopańko, M. Kozłowski, op. cit., s. 44-45.

29 Portfel służy również do przechowywania bitcoinów i może zawierać dowolną ich liczbę w postaci kluczy kryptograficznych. Więcej na temat portfeli: www.bitcoin.pl/poradniki/portfele (dostęp: 8.05.2019).

30 D. Homa, op. cit., s. 27. 
fizycznych nośnikach ${ }^{31}$. Przykładowo mogą to być fizyczne monety. Tak jak klasyczne środki płatnicze bitcoin w takiej formie może służyć do dokonywania transakcji i wymiany na towary lub usługi w punktach akceptujących taki sposób płatności.

\section{c) Blockchain — łańcuch bloków}

Tak zwany łańcuch bloków (blockchain) jest jednym z najistotniejszych elementów składających się na działanie systemu bitcoin. Można powiedzieć, że mechanizm ten jest podstawą, na której została oparta kryptowaluta. Łańcuch bloków jest całkowicie zdecentralizowany i publicznie dostępny w internecie (w postaci oprogramowania open source).

Blockchain jest to kompletny rejestr rozproszony. Oznacza to, że jest on chronologiczną bazą zapisów zawierającą liniowy zbiór informacji o wszystkich dokonanych transakcjach. Dane te są uporządkowane i zamknięte w formie bloków. Poszczególne bloki ułożone są sekwencyjnie ${ }^{32}$, a każdy kolejny $\mathrm{z}$ nich zawiera odniesienie do poprzedzającego. Łańcuch bloków stale się powiększa w wyniku dodawania przez "górników” kolejnych bloków z rejestrowanymi na bieżąco transakcjami. Proces ten następuje każdorazowo co mniej więcej 10 minut $^{33}$.

Poza publicznym dostępem blockchain cechuje też jawność i wysoka transparencja. Łańcuch bloków zawiera kompletną historię każdego bitcoina i wszelkich zawieranych wymian, co umożliwia prześledzenie przepływu konkretnej „monety” ${ }^{4}$. Pełna historia zmian właścicieli wpływa na bezpieczeństwo systemu. W przypadku próby ponownego wykorzystania tej samej jednostki kryptowaluty na rzecz innej transakcji, system uniemożliwi zawarcie wymiany i anuluje transfer.

\section{Zastosowania}

Podstawowym celem przyświecającym stworzeniu bitcoina było zmniejszenie kosztów związanych $\mathrm{z}$ handlem $\mathrm{w}$ internecie oraz wyeliminowanie jego wad ${ }^{35}$. Od początku swojego istnienia kryptowaluta miała pełnić przede wszystkim funkcję płatniczą. Bitcoin oraz jego alternatywy są wykorzystywane głównie w celu dokonywania płatności za towary bądź też usługi. Dokonywanie zakupów może się odbywać za pośrednictwem sklepów internetowych oraz w coraz większym stopniu w punktach stacjonarnych. Kryptowaluta może być też stosowana w handlu pomiędzy przedsiębiorstwami. Co istotne, możliwe jest również dokonywanie wymiany na dowolne inne tradycyjne środki służące

31 www.coinformacje.pl/2016/03/14/satori-coins-fizyczne-monety-bitcoin/ (dostęp: 12.05.2019).

32 Zdarza się jednak, że w łańcuchu bloków powstają rozgałęzienia. Więcej M. Szymankiewicz, op. cit., s. $44-45$.

33 M. Swan, Blockchain. Blueprint for a New Economy, Sebastopol 2015, s. 12.

34 Ibidem, s. 12 oraz S. Bentyn, M. Grzybkowski, op. cit., s. 27. Historie poszczególnych jednostek bitcoin lub innych kryptowalut można prześledzić za pośrednictwem wyszukiwarek internetowych, jak na przykład www.blockchain.com/explorer (dostęp: 12.05.2019).

35 S. Nakamoto, op. cit. 
do płatności. Funkcja płatnicza dotyczy wszelkich form i metod transakcji, od realizacji przelewów do różnego rodzaju rozliczeń, $\mathrm{w}$ tym także realizowanych internetowo lub za pośrednictwem urządzeń mobilnych.

Stopień anonimowości transakcji zawieranych z użyciem walut cyfrowych może być czynnikiem zachęcającym do wykorzystywania ich przez środowiska przestępcze. Jako przykład można wskazać historię działalności portalu Silk Road, gdzie właśnie bitcoin służył za główną metodę przepływu środków. Kryptowaluta była środkiem płatności za nielegalne usługi i asortyment. Warto wspomnieć, że odnotowano przypadki wykorzystywania tego rodzaju instrumentów jako narzędzie do pozyskiwania dodatkowych funduszy przez organizacje terrorystyczne ${ }^{36}$. Choć w tej kwestii można mówić o dostrzeganiu potencjału zastosowań przez terrorystów, to w przeważającej mierze metodą dokonywania przez nich płatności w dalszym ciągu pozostaje gotówka ${ }^{37}$. Wynika to $\mathrm{z}$ faktu, że transakcje gotówkowe są trudniejsze do wyśledzenia niż opierające się na rejestrach rozproszonych kryptowaluty, przez co każdy przepływ znajduje się w ogólnodostępnym spisie. Drugim czynnikiem może być bariera techniczna w dostępie do odpowiednich narzędzi umożliwiających przeprowadzenie transakcji. Dlatego można zaproponować wniosek, że transakcje dokonywane za pośrednictwem bitcoina lub innych kryptowalut są anonimowe tylko częściowo lub pozornie. Możliwe też, że w stopień anonimowości użytkowników i transakcji w przeszłości był większy, a obecnie stan ten zmienił się diametralnie.

Kryptowaluty mogą być narzędziem dokonywania transakcji, ponieważ posiadają określoną wartość. Czynnik ten może stanowić kolejny element zastosowania. Posiadanie oraz przechowywanie wartości oznacza, że ten rodzaj instrumentów można postrzegać jako metodę inwestycji. Posiadana jednostka kryptowaluty się nie przeterminowuje, co umożliwia przechowywanie i ochronę środków w teoretycznie nieograniczonej perspektywie czasowej. W takim ujęciu waluty cyfrowe przypominają złoto, na którym znaczącej mierze są wzorowane pod względem właściwości monetarnych ${ }^{38}$. Podobnie jak w wypadku metalu szlachetnego liczba jednostek waluty cyfrowej jest ściśle ograniczona. Inną cechą wspólną jest niemożliwość „dodruku”, co odnosi się czasem do tradycyjnego pieniądza. Wartość w wypadku kryptowalut wynika wyłącznie z rzadkości i ograniczeń ilościowych, będących konsekwencją zasad ich konstrukcji.

Choć bitcoin i inne kryptowaluty mogą być traktowane jako metoda inwestycji, to bardziej precyzyjne będzie traktowanie ich jako alternatywnej formy lokowania kapitału. O inwestycjach alternatywnych mowa odnośnie do metod angażowania środków innych niż lokaty, papiery wartościowe i obligacje. Sytuacja kryptowalut nie jest skorelowana $\mathrm{z}$ indeksami giełdowymi lub walutowymi, co umożliwia odgraniczenie ich od takiego rodzaju rynków ${ }^{39}$. Dodać należy, że koniunktura i kierunek zmian ceny bitcoina wska-

\footnotetext{
36 www.fxmag.pl/artykul/raport-czy-kryptowaluty-finansuja-terroryzm (dostęp: 16.05.2019).

37 www.comparic.pl/terrorysci-wola-gotowke-od-kryptowalut (dostęp: 17.05.2019).

38 G. Gilder, Standard złota w epoce pieniądza cyfrowego. Informacyjna teoria pieniądza i kredytu, przeł. J. Strzelecki, Warszawa 2015, s. 56-57.

39 D. Yermack, Is bitcoin a real currency? An economic appraisal, [w:] Handbook of Digital Currency. Bitcoin, Innovation, Financial Instruments, and Big Data, red. D. Lee Kuo Chuen, Amsterdam 2015, s. 30-34.
} 
zują, że staje się on w coraz większym stopniu instrumentem nastawionym na spekulację, zwłaszcza krótkotrwałą. Inwestycje nastawione na długofalowe i stopniowe wzrosty mogą być znacznie trudniejsze do zrealizowania. Gwałtowne ruchy i spadki ceny uwidaczniają w tej kwestii wysoki poziom ryzyka kursowego.

Osobną przestrzeń zastosowań kryptowalut stanowi rejestr rozproszony, czyli blockchain. Potencjał technologii, na której opiera się bitcoin, nie ogranicza się wyłącznie do sfery bankowości czy finansów. Wykorzystanie łańcuchów bloków może wpłynąć na liczne dziedziny i gałęzie gospodarki, takie jak branża notarialna, energetyka oraz logisty$\mathrm{ka}^{40}$. Zastosowania odnoszą się przede wszystkim do wszelkiego rodzaju rejestrów oraz procesów, w których istotnym czynnikiem może być transparentność, poziom zaufania lub duże znaczenie ma potwierdzanie autentyczności. Spekuluje się na temat wpływu systemów opartych na łańcuchach bloków w handlu międzynarodowym. Według Światowej Organizacji Handlu udział tej technologii w globalnej skali może osiągnąć wartość około 3 bilionów dolarów do 2030 roku $^{41}$. Implementacja tego typu rozwiązań może oznaczać zmniejszanie barier handlowych, głównie przez obniżenie kosztów oraz uproszczenia procesów związanych $z$ obrotem i pośrednictwem finansowym ${ }^{42}$.

Choć w literaturze zaznacza się potencjalne zastosowania, to widoczne są też próby bezpośredniego wdrażania systemów opierających się na łańcuchach bloków. Jako przykład wskazać można branżę energetyczną. Litewskie przedsiębiorstwo we współpracy z przedstawicielem sektora energetycznego Estonii zastosowało blockchain w odniesieniu do danych dotyczących poziomu produkcji i zużycia energii elektrycznej oraz związanych z nimi płatności ${ }^{43}$. Dodać można, że tym przypadku wykorzystano system związany z kryptowalutą ethereum. Natomiast w Polsce Giełda Papierów Wartościowych prowadzi prace wdrożeniowe platformy mającej na celu usprawnienie procesów obrotu instrumentami oraz zwiększenie poziomu przejrzystości w dostępie do informacji ${ }^{44}$. Planowane jest również wprowadzenie nowych rodzajów instrumentów finansowych bazujących na łańcuchach bloków.

Innym obszarem, w którym trwają prace nad implementacją technologii blockchain, jest głosowanie elektroniczne. Przeprowadzenie wyborów w takiej formie w założeniu polega na kryptograficznym potwierdzeniu prawa do głosowania, a także do przydzielenia głosów w postaci cyfrowych żetonów stanowiących odpowiednik jednostki kryptowaluty $^{45}$. W takiej sytuacji łańcuch bloków zapewnia prawidłowość działania i transparentność całego procesu. W Korei Południowej rozpoczęto przygotowania (w grudniu 2018 roku) do przeprowadzania wyborów online $\mathrm{z}$ wykorzystaniem blockchain ${ }^{46}$. W rezultacie głosowanie ma się odbyć za pośrednictwem sieci internetowej, przy użyciu kom-

\footnotetext{
40 S. Bentyn, M. Grzybowski, op. cit., s. 105-144.

${ }^{41} \mathrm{https} / / /$ comparic.pl/swiatowa-organizacja-handlu-wto-blockchain-bedzie-warty-3-bln-usd/ (dostęp: 20.05.2019).

42 E. Ganne, Can Blockchain Revolutionize International Trade?, Geneva 2018, s. 17.

43 www.bithub.pl/wiadomosci/energetyka-estonii-przechodzi-na-blockchain/ (dostęp: 22.05.2019).

44 www.businessinsider.com.pl/gielda/wiadomosci/gpw-blockchain-projekt-platformy-dla-stokenizowanych-aktywow/pqb49fr (dostęp: 22.05.2019).

45 S. Bentyn, M. Grzybowski, op. cit., s. 113.

46 www.zdnet.com/article/south-korea-to-develop-blockchain-voting-system/ (dostęp: 23.05.2019).
} 
puterów lub urządzeń przenośnych. System łańcuchów bloków pełni w tym kontekście funkcję uwierzytelniania danych osób głosujących. Dodatkowo łańcuch bloków może posłużyć do szacowania wyników i rozkładu głosów. Warto dodać, że nie jest to pierwsza i jedyna tego typu inicjatywa. Prace nad wdrożeniem podobnych rozwiązań trwają lub są zaplanowane na najbliższe lata. W państwach takich jak Japonia, Szwajcaria, a także w Polsce trwają w tym zakresie dyskusje i działania związane z przeprowadzaniem wyborów w formie elektronicznej, opartej na systemach łańcuchów bloków.

Blockchain jest też elementem kryptowalut, nad którym trwają czynności dotyczące kodyfikacji oraz wprowadzania rozwiązań ustawowych. Poszczególne państwa dostrzegają wynikające z mechanizmu potencjalne korzyści oraz konsekwencje. Również agendy Unii Europejskiej zajmują się tym zagadnieniem. Parlament Europejski podjął kroki w postaci wydania uchwały nawołującej do stworzenia podstaw prawnych ${ }^{47}$. Założeniem tego rodzaju rozwiązań jest dążenie do adaptacji technologii opartych na łańcuchach bloków na rzecz celów gospodarczych i handlu w obrębie państw członkowskich.

\section{Kwestia regulacji prawnych}

Pierwszym wyraźnym obszarem, w którym rozwój kryptowalut przełożył się na reakcje ze strony aktorów politycznych, była sfera prawna i prawodawstwo. Problematyka w tej kwestii odnosi się do konkretnych gałęzi prawa. Szczególne wyzwania uwidoczniły się na gruncie prawa cywilnego, karnego oraz $\mathrm{w}$ istotnej mierze $\mathrm{w}$ zakresie podatkó $\mathrm{w}^{48}$. Trudności w dziedzinie legislacji dotyczą definicji kryptowalut oraz kwestii ich uznania za legalny środek płatniczy. W wypadku prób stosowania istniejących regulacji wysoce problematyczne jest założenie wymogu istnienia centralnego emitenta ${ }^{49}$. Z punktu widzenia prawa konieczny jest podmiot ponoszący odpowiedzialność prawną, natomiast charakter walut cyfrowych wyklucza występowanie wszelkich ośrodków centralnych.

Widoczne jest zróżnicowanie podejście ze strony państw w odniesieniu do prób regulacji tego rodzaju instrumentów. Wyszczególnić można w tym kontekście trzy rodzaje podejmowanych działań. W pierwszym przypadku państwa mogą poddawać kryptowaluty procesowi regulacji. Drugim wariantem jest dążenie do ograniczenia lub eliminacji ich stosowania. Ostatnie podejście polega na zachowaniu obecnego status quo i oczekiwaniu. Takie zróżnicowanie jest wynikiem odmiennej percepcji państw na zjawisko walut cyfrowych oraz sposobu postrzegania ich jako formy środka płatniczego. Istotnym czynnikiem determinującym podejście regulacyjne jest kwestia braku centralnego emitenta.

47 www.fxmag.pl/artykul/parlament-europejski-chce-rozwijac-technologie-blockchain (dostęp: 25.05.2019).

48 Szerzej na temat problematyki prawnej kryptowalut oraz sytuacji natury podatkowej: M. Michnia, Bitcoin jako przedmiot stosunków cywilno-prawnych, Warszawa 2018, s. 13-17.

49 J. Czarnecki, Prawne aspekty zastosowań technologii blockchaina na rynkach finansowych, [w:] Regulacje finansowe. FinTech - nowe instrumenty finansowe - resolution, red. W. Rogowski, Warszawa 2017, s. 50 . 
Przykładem państwa otwartego i aktywnie dostosowującego swój system prawny wobec zjawiska walut cyfrowych jest Szwajcaria. Państwem reprezentującym przeciwne podejście są Chiny, będące także pierwszym przykładem wprowadzenia delegalizacji kryptowalut. Chiński bank centralny wyznaczył szeroki zakres ograniczeń skierowany do instytucji finansowych ${ }^{50}$. Uniemożliwiło to w pośredni sposób posługiwanie się bitcoinem przez tego rodzaju podmioty. Stanowisko Chin zdaje się być w tej kwestii stabilne i niezmienne. Zmiana w sposobie podejścia zauważalna jest w wypadku Rosji. Początkowo państwo to dążyło do wprowadzenia sankcji karnych za dystrybucję kryptowalut lub ich wymianę na ruble. Nastąpiła jednak zmiana orientacji i rozpoczęto prace nad przygotowaniami prawnymi na rzecz legalizacji. Rosja zainicjowała również działania mające na celu wprowadzenie własnej narodowej kryptowaluty ${ }^{51}$.

Zaznaczyć należy, że występowanie restrykcji nie oznacza jednocześnie zakazu posiadania lub stosowania walut cyfrowych przez osoby fizyczne. Ograniczenia koncentrują się na dystrybucji, wymianie oraz uniemożliwianiu przeprowadzenia ICO. Obostrzenia kierowane są przede wszystkim wobec podmiotów wspierających obrót kryptowalutami. Podkreśla się przy tym zakres ryzyka i zagrożenia dla potencjalnego użytkownika.

Brak jakichkolwiek regulacji może sprzyjać potencjalnym nadużyciom i przestępstwom. Rozwiązania prawne mają na celu przeciwdziałanie przestępstwom finansowym i ograniczenie procederu wprowadzania do obiegu środków pochodzących z nielegalnych źródeł. Szczególnym procederem w kontekście tego rodzaju instrumentów są kradzieże, występujące głównie przy realizacji ICO. Państwa starają się też zapobiegać i minimalizować możliwości wykorzystywania kryptowalut przez organizacje przestępcze oraz mające charakter terrorystyczny.

Procesy prawne dotyczące walut cyfrowych podlegają ciągłej ewolucji. W przeważającej liczbie przypadków podjęcie kroków o charakterze legislacyjnym nie jest równoznaczne $\mathrm{z}$ ustanowieniem kryptowalut jako legalnej formy płatności ${ }^{52}$. Wprowadzane regulacje raczej nie zawierają propozycji definicji prawnych kryptowalut, nie określają też zakresu ich działania, a koncentrują się na rozwiązaniach dotyczących infrastruktury, wokół której funkcjonują ${ }^{53}$. Warto dodać, że zmiany prawne lub ich kierunek, mogą mieć wpływ na postrzeganie potencjału i wartości samych instrumentów.

\section{Polityczne implikacje bitcoina oraz innych kryptowalut}

Poszczególne państwa dostrzegły możliwości wynikające z kryptowalut. W konkretnych przypadkach stały się one nowymi narzędziami w realizacji określonych celów i założeń

50 S. Bala, T. Kopyściański, W. Srokosz, Kryptowaluty jako elektroniczne instrumenty płatnicze bez emitenta. Aspekty informatyczne, ekonomiczne i prawne, Wrocław 2016, s. 118-119.

51 www.bitcoin.pl/rosja-reguluje-rynek-kryptowalut-i-planuje-emisje-stablecoina/ (dostęp: 3.06.2019).

52 Także w Polsce są widoczne ruchy zmierzające do regulacji. Dodać należy, że w polskim prawie kryptowaluty nie są traktowane jako legalny środek płatniczy. Wynika to bezpośrednio z treści ustawy o Narodowym Banku Polskim z dnia 29 sierpnia 1997 roku — artykuł 31 i 32 (Dz.U. z 1997 r. Nr 140, poz. 938).

53 P. Lis Markiewicz, S. Nowak, op. cit., s. 81. 
politycznych. W okresie od 2017 do pierwszej połowy 2019 roku, w doniesieniach medialnych przejawiały się w tym zakresie działania kilku określonych aktorów państwowych.

Pierwszym przypadkiem jest aktywność Wenezueli, która dokonała próby wprowadzenia do publicznej sprzedaży państwowej kryptowaluty - Petro (PTR). Wejście projektu na rynek planowano na listopad 2018 roku. Instrument w założeniu miał mieć oparcie w postaci zasobów surowcowych tego państwa, głównie ropy naftowej ${ }^{54}$. Rząd Wenezueli zapewniał, że każda jednostka kryptowaluty będzie mieć swój odpowiednik $\mathrm{w}$ baryłce tego zasobu. Petro w swoim założeniu miało też podlegać wymianie na inne środki płatnicze, $w$ tym waluty $w$ tradycyjnej lub cyfrowej formie ${ }^{55}$. Wprowadzenie koncepcji w życie miało na celu wzmocnienie gospodarki tego państwa, znajdującego się w trakcie poważnego kryzysu i zapaści ekonomicznej. Oczekiwano, że petro znajdzie zastosowanie $\mathrm{w}$ obszarze handlu, finansów oraz $\mathrm{w}$ sferze polityki pieniężnej. $\mathrm{W}$ rezultacie kryptowaluta miała być pomocna w walce $\mathrm{z}$ hiperinflacją i mieć pozytywny wpływ na sytuację gospodarczą Wenezueli. Znaczący jest też fakt, że stworzenie petro w pewnym zakresie miało być metodą obejścia sankcji nałożonych przez Stany Zjednoczone ${ }^{56}$.

Przykład działalności Wenezueli jest jednym z bardziej kontrowersyjnych prób wdrażania i wykorzystania kryptowaluty. Dyskusje dotyczą nie tylko faktycznych motywów politycznych, lecz w znaczącej mierze transparencji oraz kwestii tego, czym w istocie miało być petro. W rzeczywistości instrument ten sprowadzał się do próby stworzenia nie kryptowaluty w ścisłym znaczeniu, a cyfrowego tokena, co sprawiło, że cały projekt postrzegano jako wątpliwy ${ }^{57}$. W dodatku rządowe założenia poprawy stanu gospodarki nie zostały w żadnym stopniu osiągnięte. Przypadek ten sugeruje bardziej próbę wykorzystania trendu popularności walut cyfrowych przez państwo, niż faktyczne wprowadzenie realnego instrumentu do obrotu. Niemniej, aktywność Wenezueli pokazuje zainteresowanie tego typu instrumentami jako metody osiągnięcia celów politycznych. Sam projekt jest także pierwszą próbą przeprowadzenia ICO przez państwo.

Zainteresowanie możliwościami zastosowania kryptowalut jest widoczne także w Iranie. Kryzys relacji ze Stanami Zjednoczonymi oraz napięcia wokół irańskiego programu nuklearnego poskutkowały nałożeniem na to państwo sankcji gospodarczych. Kolejnym dotkliwym dla Iranu wydarzeniem było wykluczenie go z międzynawowego sytemu SWIFT ${ }^{58}$. Sankcje poskutkowały utrudnieniami w przeprowadzaniu transakcji zagranicznych. Słabnąca waluta i narastające problemy gospodarcze spowodowały rozpoczęcie poszukiwań ze strony Iranu alternatywnych sposobów płatności międzynarodowych oraz możliwości unikania sankcji. W tym celu przygotowano grunt prawny pod

54 www.cryptoprofit.pl/petro-kryptowaluta-wenezueli/ (dostęp: 5.06.2019).

55 www.bithub.pl/wiadomosci/wenezuelskie-petro-zamienimy-na-dowolna-kryptowalute/ (dostęp: 5.06. 2019).

56 Ibidem.

57 www.fxmag.pl/artykul/petro-kryptowaluta-wenezueli-hiperinflacja-maduro (dostęp: 5.06.2019).

58 SWIFT to ogólnoświatowy system wymiany informacji pomiędzy bankami i instytucjami finansowymi. System ten pośredniczy w transakcjach międzynarodowych. 
stworzenie kryptowaluty opartej na złocie - peyman ${ }^{59}$. Irańska waluta cyfrowa zaczęła funkcjonować z początkiem 2019 roku. Założeniem projektu było ułatwienie transferów pieniężnych z dowolnymi podmiotami na całym świecie ${ }^{60}$. „Kryptorial” był również próbą stworzenia alternatywy dla globalnego systemu scentralizowanej bankowości.

Trudno mówić o efektach czy też skuteczności funkcjonowania irańskiej kryptowaluty na rzecz omijania sankcji. Zauważalne były jednak kontrdziałania ze strony Stanów Zjednoczonych. Państwo to wyraźnie dążyło do blokowania Iranowi możliwości tworzenia walut cyfrowych i rozwijania sektorów finansowych opierających się na technologii łańcuchów bloków ${ }^{61}$. W tym celu Stany Zjednoczone rozpoczęły procesy prawne oraz monitorowanie potencjalnych przepływów środków, a także wezwały do anulowania transakcji, które mogły być dokonane przez Iran.

Kolejnym przykładem prób omijania sankcji gospodarczych jest Korea Północna. Wykorzystanie przez to państwo kryptowalut, a konkretnie bitcoina, także i w tym przypadku odnosiło się do omijania wykluczeń nałożonych przez Stany Zjednoczone ${ }^{62}$. Korea Północna upatrywała w zastosowaniu walut cyfrowych sposobu przeprowadzania wymian z innymi państwami, maskowania dokonywanych płatności lub operacji oraz otwarcia możliwości korzystania z usług międzynarodowych instytucji finansowych, także tych powiązanych ze Stanami Zjednoczonymi. Nie wyklucza się tė̇, że rząd koreański rozpoczął prace nad projektem własnej kryptowaluty. Tak jak w podobnych przypadkach, głównym celem takiego instrumentu miałoby być poszerzenie możliwości dalszego omijania restrykcji ekonomicznych.

Innym przejawem działań Korei Północnej w kontekście kryptowalut jest realizowana na zlecenie tego państwa aktywność hakerska. Szacuje się, że w wyniku cyberataków rząd koreański uzyskał środki w wysokości około 670 milionów dolarów ${ }^{63}$. Obiektami ataków były przede wszystkim instytucje finansowe, depozyty oraz giełdy kryptowalutowe. Celem hakerów prawdopodobnie były także portfele indywidualnych użytkowników ${ }^{64}$. Kradzieże przeprowadzano przede wszystkim w celu zwiększenia środków rządowych, poprawy sytuacji budżetowej oraz na rzecz zdobycia instrumentów do omijania sankcji ekonomicznych.

Ostatnim przykładem aktora politycznego poszukującego możliwości unikania restrykcji gospodarczych za pośrednictwem kryptowalut jest Rosja. Państwo to brało pod uwagę zastosowanie bitcoina jako alternatywy wobec dolara amerykańskiego w handlu

59 www.bitcoinexchangeguide.com/iran-has-launched-a-gold-backed-cryptocurrency-peyman-in-effort-to-avoid-us-sanctions/ (dostęp: 8.06.2019).

60 www.digitalassets.pl/iran-przygotowuje-grunt-pod-narodowa-kryptowalute-aby-uniknac-amerykanskich-sankcji/ (dostęp: 8.06.2019).

61 www.coinfomania.com/us-regulator-advise-crypto-exchanges-to-monitor-iran/ (dostęp: 10.06.2019).

62 www.comparic.pl/korea-polnocna-omija-sankcje-za-pomoca-kryptowalut/ (dostęp: 10.06.2019).

63 https://comparic.pl/korea-polnocna-podejrzana-o-kradziez-kryptowalut-wartych-670-mln-usd/ (dostęp: 11.06.2019).

64 www.fxmag.pl/artykul/korea-polnocna-kradnie-kryptowaluty-zwyklych-uzytkownikow (dostęp: 11.06.2019). 
międzynarodowym ${ }^{65}$. Władze rosyjskie rozpatrywały też działania inwestycyjne w postaci wymiany znacznej ilości dolarów na kryptowaluty.

Bitcoin i inne waluty cyfrowe mogą być traktowane przez państwa jako wyzwanie $\mathrm{w}$ wymiarze bezpieczeństwa. Przeprowadzanie transakcji za pomocą tego typu instrumentów wiąże się z określonym poziomem anonimowości. $\mathrm{W}$ teorii może to skutkować wykorzystywaniem kryptowalut przez grupy przestępcze lub terrorystyczne. Nielegalna aktywność w istotnej mierze związana jest $\mathrm{z}$ tak zwanym Dark Webem oraz siecią TOR. Historia portalu Silk Road pokazuje, że kryptowaluty mogą służyć jako metoda płatności za nielegalne towary, takie jak broń czy narkotyki. Znaczna anonimowość transakcji, w połączeniu z decentralizacją, może być użyteczna na rzecz procederu „prania brudnych pieniędzy" ${ }^{\prime \prime 6}$. Same waluty cyfrowe oraz różne związane $\mathrm{z}$ nimi usługi także stały się obiektem zainteresowania przestępców. Intensyfikuje się zjawisko kradzieży i ataków hakerskich na użytkowników prywatnych i podmioty gospodarcze.

Warto zaznaczyć, że wystąpiły przypadki finansowania działalności organizacji terrorystycznych za pomocą kryptowalut. Pierwszym przykładem jest udzielenie wpłat za pośrednictwem bitcoinów na rzecz ugrupowania Hamas ${ }^{67}$. Niewielkie kwoty zostały przesłane na portfel organizacji dwukrotnie. Drugim przykładem jest próba udzielenia wsparcia finansowego Państwu Islamskiemu przez obywatelkę Stanów Zjednoczonych $^{68}$. Sprawa miała miejsce 2017 roku i zakończyła się aresztowaniem podejrzanej i rozpoczęciem procesu karnego.

Wskazane przykłady pokazują, że choć kryptowaluty mogą w określonym zakresie być narzędziem wykorzystywanym przez grupy terrorystyczne, to jednak instrumenty te nie gwarantują pełnej anonimowości użytkowników. Stwarza to możliwości działania służbom państwowym. Obecnie jeszcze trudno proponować precyzyjne wnioski mówiące o skali procederu wykorzystywania walut cyfrowych przez środowiska o charakterze przestępczym lub terrorystycznym. Fenomen kryptowalut zaistniał stosunkowo niedawno, przez co dopiero powstają sposoby zwalczania przestępczości z ich wykorzystaniem. Poszczególne instytucje i służby dążą do zwiększenia kontroli nad tego rodzaju instrumentami, szerszego monitorowania nielegalnej działalności oraz przeciwdziałania przestępstwom w celu zapewnienia bezpieczeństwa obywateli i ich środków ${ }^{69}$. Stąd też $\mathrm{w}$ wielu państwach prowadzone są prace nad rozwiązaniami prawnymi mającymi ograniczyć przestępczość związaną z kryptowalutami.

65 www.cryptogogle.com/rosja-bitcoin-usd/ (dostęp: 11.06.2019).

66 M. Campbell-Verduyn, M. Goguen, The mutual constitution of technology and global governance. Bitcoin, blockchains, and the international anti-money-laundering regime, [w:] Bitcoin and Beyond. Cryptocurrencies, Blockchains, and Global Governance, red. M. Campbell-Verduyn, London 2018, s. 74-75.

67 www.bithub.pl/wiadomosci/hamas-prosby-o-wsparcie-w-postaci-bitcoinow-wysluchane/ (dostęp: 13.06.2019).

68 https://comparic.pl/wykorzystala-bitcoina-btc-finansowania-isis-grozi-jej-20-lat-wiezienia/ (dostęp: 13.06.2019).

69 M. Skwarska, Kryptowaluty. Rewolucja czy chwilowy eksperyment? Wyzwania dla administracji i bezpieczeństwa państwa, „Kwartalnik Policyjny” 2018, nr 3 (46), s. 103. 


\section{Podsumowanie}

Powstanie bitcoina i jego rozwój zapoczątkowało wiele implikacji widocznych w różnych obszarach. Szerokie spektrum możliwości zastosowań oraz rosnąca popularność przełożyły się na powstawanie kolejnych kryptowalut. Dlatego też o bitcoinie należy mówić w kategorii szerszego zjawiska. Fenomen ten znalazł również odzwierciedlenie w sferze politycznej, w której widoczne jest zainteresowanie i próby implementacji walut cyfrowych przez poszczególne państwa. Przykłady takiego ich zastosowania przez aktorów politycznych odnoszą się do konkretnych płaszczyzn ich aktywności i funkcjonowania.

Kryptowaluty mają charakterystyczne właściwości, do których należą przede wszystkim niematerialność i sieciowość. Istotne znaczenie ma też, że podobnie jak tradycyjne waluty posiadają one określoną wartość. Znaczącą cechą jest także decentralizacja oznaczająca niezależność od wszelkich instytucji państwowych.

Waluty cyfrowe opierają się na konkretnych rozwiązaniach technologicznych, przez co pełnią określone funkcje. Pierwszą z nich jest dokonywanie transakcji i wymian. Kryptowaluty są metodą płatności za towary i/lub usługi. Znaczący w tym kontekście jest poziom anonimowości stron przeprowadzających operację. Druga z funkcji odnosi się do wartości, która sprawia, że instrument może być formą inwestycji lub alternatywną metodą alokacji środków. Ostatnim elementem zastosowań jest łańcuch bloków. Główny „mechanizm”, na którym opiera się działanie kryptowalut, stwarza szerokie możliwości wykorzystania. Zastosowanie może obejmować wiele dziedzin gospodarki, w tym handel międzynarodowy czy sektor energetyczny. Z tego względu blockchain rozwija się w sposób niezależny od kryptowalut. Ponadto w poszczególnych państwach widoczne są prace zmierzające do wdrożenia wykorzystujących tę technologię platform do głosowania elektronicznego. Dlatego można zaproponować twierdzenie, że mechanizmy umożliwiające działanie walut cyfrowych mogą przyczynić się pośrednio do rozwoju systemów e-votingu.

Wpływ kryptowalut w odniesieniu do przestrzeni politycznej zauważalny jest zasadniczo w obszarze prawa, bezpieczeństwa oraz w odniesieniu do kwestii międzynarodowych sankcji gospodarczych. W wypadku legislacji można mówić o procesie przechodzenia od prohibicji do akceptacji i regulacji. Zjawisko to wzbudziło potrzeby stworzenia norm prawnych na rzecz zabezpieczeń własności oraz w kontekście uwidocznionych przez nie luk w zakresie podatków. Zaznaczyć należy, że procesy legalizacyjne odnoszące się do walut cyfrowych nie oznaczają jednocześnie uznawania ich za pełnoprawny środek płatniczy.

Z punktu widzenia bezpieczeństwa kryptowaluty i związany z nimi poziom anonimowości transakcji mogą być zastosowane w działalności o nielegalnym charakterze. Dotyczy to przede wszystkim aktywności zorganizowanych grup przestępczych oraz procederu „prania brudnych pieniędzy”. Prowadzone są też dyskusje, czy waluty cyfrowe są stosowane przez organizacje terrorystyczne. W efekcie można mówić o dążeniach na rzecz zwiększenia kontroli i monitoringu ze strony organów i instytucji odpowiedzialnych za bezpieczeństwo państwowe. 
Właściwości kryptowalut sprawiły, że poszczególne państwa podjęły próby ich użycia jako narzędzia w odniesieniu do omijania lub zmniejszenia skutków sankcji gospodarczych. Wśród aktorów wykazujących aktywność w tym zakresie znajdują się Wenezuela, Iran, Korea Północna oraz Rosja. Przykłady działań Wenezueli i Korei Północnej pokazują w dodatku dążenia do zastosowania kryptowalut w celu poprawy sytuacji gospodarczej oraz zwiększenia rządowych zasobów finansowych. Zaznaczyć należy, że dalsze próby wykorzystywania tego rodzaju instrumentów w celu unikania sankcji międzynarodowych mogą być czynnikiem destabilizującym i skutkować większymi antagonizmami w relacjach pomiędzy państwami.

Omawiany fenomen zaistniał relatywnie niedawno, a skutki jego oddziaływań w przestrzeni politycznej ograniczają się do określonych obszarów i przypadków. Choć obecnie waluty cyfrowe mogą być postrzegane jako instrumenty o charakterze alternatywnym lub niszowym, to ich dalszy rozwój może prowadzić do szerszego zakresu ich oddziaływania na poszczególne obszary funkcjonowania aktorów państwowych. Z tego powodu kryptowaluty mogą być ciekawym przedmiotem dalszych obserwacji z punktu widzenia państw i procesów politycznych.

\section{Bibliografia}

\section{Źródła}

Nakamoto S., Bitcoin: A Peer-to-Peer Electronic Cash System, www.bitcoin.org/bitcoin.pdf (dostęp: 2.05.2019). Ganne E., Can Blockchain Revolutionize International Trade?, Geneva 2018.

Ustawa o Narodowym Banku Polskim z dnia 29 sierpnia 1997 roku (Dz.U. z 1997 r. Nr 140, poz. 938).

\section{Literatura}

Antonopoulos A.M., Bitcoin dla zaawansowanych. Programowanie z użyciem otwartego łańcucha bloków, przeł. T. Walczak, Gliwice 2018.

Bala S., Kopyściański T., Srokosz W., Kryptowaluty jako elektroniczne instrumenty płatnicze bez emitenta. Aspekty informatyczne, ekonomiczne i prawne, Wrocław 2016.

Bentyn S., Grzybowski M., Kryptowaluty. Dlaczego jeden bitcoin wart będzie milion dolarów?, Poznań 2018. Bitcoin and Beyond. Cryptocurrencies, Blockchains, and Global Governance, red. M. Campbell-Verduyn, London 2018.

Ekonomia od A do Z, red. S. Sztaba, Warszawa 2007.

Franco P., Understanding Bitcoin. Cryptography, Engineering and Economics, Padstow 2015.

Gilder G., Standard złota w epoce pieniądza cyfrowego. Informacyjna teoria pieniądza i kredytu, przeł. J. Strzelecki, Warszawa 2015.

Guttman B., The Bitcoin Bible Gold Edition. All You Need to Know About Bitcoins and More, Norderstedt 2013.

Handbook of Digital Currency. Bitcoin, Innovation, Financial Instruments, and Big Data, red. D. Lee Kuo Chuen, Amsterdam 2015.

Homa D., Sekrety bitcoina i innych kryptowalut. Jak zmienić wirtualne pieniądze w realne zyski, Gliwice 2015. Kopańko K., Kozłowski M., Bitcoin. Złoto XXI wieku, Gliwice 2015. 
Lis Markiewicz P., Nowak S., Bitcoin. Przyszłość inwestowania, Warszawa 2015.

Michnia M., Bitcoin jako przedmiot stosunków cywilno-prawnych, Warszawa 2018.

Pieniadz wirtualny i determinanty jego rozwoju w sferze ekonomii, finansów, prawa, red. E. Bogacka-Kisiel, Opole 2013.

Piotrowska A.I., Bitcoin. Płatnicze i inwestycyjne zastosowanie kryptowaluty, Warszawa 2018.

Regulacje finansowe. FinTech - nowe instrumenty finansowe - resolution, red. W. Rogowski, Warszawa 2017. Swan M., Blockchain. Blueprint for a New Economy, Sebastopol 2015.

Szymankiewicz M., Bitcoin. Wirtualna waluta internetu, Gliwice 2014.

Transakcje i monety internetowe. Kryptologia a biznes - bezpieczeństwo stosowane, red. M. Węgrzyn, J. Jabłoński, M. Nowakowski, Legionowo 2014.

\section{Periodyki}

CGAP Brief, 23 January, 2014, www.cgap.org/sites/default/files/Brief-Bitcoin-versus-Electronic-Money-Jan-2014.pdf (dostęp: 30.04.2019).

„Engineering \& Technology" 9, 2014, nr 4.

„Kwartalnik policyjny” 2018, nr 3 (46).

\section{Netografia}

https://comparic.pl/korea-polnocna-podejrzana-o-kradziez-kryptowalut-wartych-670-mln-usd/ (dostęp: 11.06.2019). https://comparic.pl/swiatowa-organizacja-handlu-wto-blockchain-bedzie-warty-3-bln-usd/ (dostęp: 20.05.

2019).

https://pl.investing.com/crypto/currencies (dostęp: 5.05.2019).

www.bankier.pl/wiadomosc/Kurs-bitcoina-spada-z-sila-wodospadu-Gwaltownie-traca-takze-inne-

kryptowaluty-7627478.html (dostęp: 8.05.2019).

www.bitcoin.org/pl/faq (dostęp: 29.04.2019).

www.bitcoin.pl/rosja-reguluje-rynek-kryptowalut-i-planuje-emisje-stablecoina (dostęp: 3.06.2019).

www.bitcoin.pl/97-publicystyka/422-przed-i-po-silk-road-1-0-ewolucja-internetowego-czarnego-rynku (dostęp: 3.05.2019).

www.bitcoin.pl/poradniki/portfele (dostęp: 8.05.2019).

www.bitcoin.pl/wiadomosci/bezpieczenstwo/1212-craig-wright-nie-jest-satoshim-nakamoto-oszustzdemaskowany (dostęp: 2.05.2019).

www.bitcoinexchangeguide.com/iran-has-launched-a-gold-backed-cryptocurrency-peyman-in-effort-toavoid-us-sanctions/ (dostęp: 8.06.2019).

www.bithub.pl/wiadomosci/energetyka-estonii-przechodzi-na-blockchain/ (dostęp: 22.05.2019).

www.bithub.pl/wiadomosci/hamas-prosby-o-wsparcie-w-postaci-bitcoinow-wysluchane/ (dostęp: 13.06. 2019).

www.blockchain.com/explorer (dostęp: 12.05.2019).

www.businessinsider.com.pl/gielda/wiadomosci/gpw-blockchain-projekt-platformy-dla-stokenizowanych-

aktywow/pqb49fr (dostęp: 22.05.2019).

www.coinfomania.com/us-regulator-advise-crypto-exchanges-to-monitor-iran/ (dostęp: 10.06.2019).

www.coinformacje.pl/2016/03/14/satori-coins-fizyczne-monety-bitcoin/ (dostęp: 12.05.2019).

www.comparic.pl/korea-polnocna-omija-sankcje-za-pomoca-kryptowalut (dostęp: 10.06.2019).

www.comparic.pl/terrorysci-wola-gotowke-od-kryptowalut/ (dostęp: 17.05.2019).

https://comparic.pl/wykorzystala-bitcoina-btc-finansowania-isis-grozi-jej-20-lat-wiezienia/ (dostęp: 13.06.

2019).

www.cryptogogle.com/rosja-bitcoin-usd/ (dostęp: 11.06.2019). 
www.dailydot.com/layer8/silk-road-3-blake-benthall/ (dostęp: 3.05.2019).

www.digitalassets.pl/iran-przygotowuje-grunt-pod-narodowa-kryptowalute-aby-uniknac-amerykanskichsankcji/ (dostęp: 8.06.2019).

www.fxmag.pl/artykul/korea-polnocna-kradnie-kryptowaluty-zwyklych-uzytkownikow (dostęp: 11.06.2019).

www.fxmag.pl/artykul/parlament-europejski-chce-rozwijac-technologie-blockchain (dostęp: 25.05.2019).

www.fxmag.pl/artykul/raport-czy-kryptowaluty-finansuja-terroryzm (dostęp: 16.05.2019).

www.money.pl/impact17/,25,0,2393881.html (dostęp: 5.05.2019).

www.money.pl/pieniadze/bitcoin/bitstamp,BTCSTAMPUSD,USD.html (dostęp: 5.05.2019).

www.newsweek.com/2014/03/14/face-behind-bitcoin-247957.html (dostęp: 2.05.2019).

www.zdnet.com/article/south-korea-to-develop-blockchain-voting-system/ (dostęp: 23.05.2019).

\section{Bitcoin and political implications of the crypto-currencies}

Keywords: Bitcoin, blockchain, crypto-currencies, economic sanctions, state

\section{Summary}

The article focuses on analyzing Bitcoin, its crucial features and applications of crypto-currencies in the context of political consequences. These kinds of instruments have value and their role as a means of payment has been constantly increasing. The attempts to use crypto-currencies by countries that actively try to take advantage of their specific functions and mechanisms is noticed. One of the particular areas of activity aims to bypass economic sanctions. In this situation, the following actors, such as Venezuela, Iran, North Korea, and Russia may be pointed out. As an addition to activities directed at avoiding sanctions, there are also projects of creating crypto-currencies by the state. In essence, these actions are supposed to improve the economic situation of particular actors. Crypto-currencies also bring challenges which are related to the processes of functioning of the state. Law and security are the main areas in this regard. 